臨床 単クローン性 IgA 血症を伴う Waldenström 型

\title{
$\mathrm{B}$ 細胞腫瘍の 1 例
}

\author{
大阪医科大学第一内科 \\ 菱谷好高〉山本隆一 中村幸枝茂在 敏司 \\ 京都大学医学㸉内科第一講演 \\ 加納 正 安田 典正
}

\section{A CASE OF WALDENSTRÖM-LIKE B CELL NEOPLASM WITH MONOCLONAL IgA SECRETION}
Yoshitaka Hishitani, MD, Ryuichi Yamamoto, MD, Yukie Nakamura, MD and Toshiji MozaI, MD
The First Department of Internal Medicine, Osaka Medical College, Takatsuki Tadashi KanoH, MD and Norimasa Yashuda, MD

The First Department of Internal Medicine, Faculty of Medicine, Kyoto University, Kyoto

\begin{abstract}
概要 原発性マクログロプリン血症の病像を呈しながら，IgA型M成分を伴う症例を経験した ので報告する。症例：56才，男性．白血球増加の精查のため入院．軽度の肝腫を認めるる脾 腫，リンパ節腫大はなし，末梢血では約 $90 \%$ ガリンパ球よりなる白血球堌加（27600）を認め, 骨髄ではりンバ球段階のものから形質細胞にいたるまでの多彩な形態を示す腫瘍細胞の著明な 増殖を認めた。血清中には $4.2 \mathrm{~g} / \mathrm{dl}$ に達する大量の $\mathrm{IgA} \kappa$ 型のM成分を認めた。このM成分の抗 idiotype抗体を作製し，これを用いて本例にみられる多彩な形態を示すリンバ系細胞が同一ク ローンに由来することを明らかにした。束た本例の末梢血リンパ球と正常人下細胞の混合培養 (PWM刺激) で，リンパ球から形質細胞への分化がみとめられ，これらはIgA $x$ 型を産生して いた，一般にIgM産生細胞の腫湟化（多くのCLL，原発性マクログロブリン血症）とIgG, IgA 産生細胞の腫痬化(骨䯣腫)は異なつた病像を呈する。本例はIgA産生細胞の腫瘍化でありなが ら，むしろ前者の病像に近い。したがつて本例は両者を関保つける特異な病像としてとらえる ことができ，B細胞腫場の連続的な相互関係を考察する上で示唆に富む貴重な症例と考えられ た.
\end{abstract}

\section{1. 緒言}

原発住マクログロブリン血症 (Waldenström) は，血清中にIgM型M成分の出現，リンパ節，骨髄 へのリンパ球ないし形質細胞，つまりBリンパ球 の各成熟段階を示す多彩な細胞の浸潤を認め, し ばしば肝脾尰を伴う。このような原発性マクログ ロプリン血症の典型的症例は, $\operatorname{lgG}, \operatorname{Ig} \mathrm{A}, \operatorname{IgD}, \lg \mathrm{E}$

[昭积56年 6 月 26 日受稿]
などのM成分を伴う骨髄腫とは明らかに臨床, 病 理像を異にしている。ところが上述の原発性マク ログロブリン血症の病像を旺しながら，明瞭な IgGあるいはIgA型M成分を伴う症例の報告が近

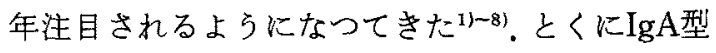
M成分を伴ら例は極めて希で，ここに報告する本 例を含めてわずかに 7 例にすぎない(1)315)6/8)．かか る症例は単に希であるばかりでなく、B細胞腫瘍 の相互関係を考元る上で示唆に富久貴重である。 
ここでは本例の検索を通して，その病像の特徵を 述べるとともに，本例にみられたリンパ球より， 形質細胞にいたる多彩なリンパ系の腫場細胞につ いて行なつた免疫学的分析結果についても考察す る.

\section{2. 症 例}

患者：56才, 男性, 無職。

主訴：白血球増加の精査.

家族歴：特記すべきことはない。

既往歴：10年来, アルコール中毒症にて加療 中.

現病歴：1980年 7 月にリンパ球が大多数を占 める白血球増加と，血清蛋白異常 (IgA型M成分) を偶然指摘され,精查のため本院内科に入院した. そのための自覚症状はとくになかつた。

入院時現症：身長 $155 \mathrm{~cm}$, 体重 $50 \mathrm{~kg}$, 脈拍 $68 /$ 分，整．眼䀫結膜に軽度貧血を認める。リンパ節 は頝部に小豆大 1 個のみ触知. 胸部の理学的所見 に異常なし.腹部では肝臓を心窩部で 1 横指触知, 弾性硬。脾臓は触知せず。神経学的に異常なし。

\section{表 1、入院時検查成績}

\begin{tabular}{|c|c|}
\hline RBC & $293 \times 10^{4} / \mathrm{mm}^{3}$ \\
\hline $\mathrm{Hb}$ & $9.5 \mathrm{~g} / \mathrm{dl}$ \\
\hline $\mathrm{Ht}$ & $29.2 \%$ \\
\hline$W B C$ & $27600 / \mathrm{mm}^{3}$ \\
\hline Stab & $3 \%$ \\
\hline Seg & $6 \%$ \\
\hline Mono & $1 \%$ \\
\hline Lymphoid & $90 \%$ \\
\hline Platelet & $10.8 \times 10^{4} / \mathrm{mm}^{3}$ \\
\hline \multicolumn{2}{|l|}{ Bone marrow } \\
\hline NCC & $17.7 \times 10^{4} \mathrm{~mm}^{9}$ \\
\hline$M: E$ & 3.54 \\
\hline Lymphoid cells & $57.0 \%$ \\
\hline Plasma cel1s & $2.6 \%$ \\
\hline GOT & $24 \mathrm{mU} / \mathrm{ml}$ \\
\hline GPT & $27 \mathrm{mU} / \mathrm{ml}$ \\
\hline LDH & $142 \mathrm{mU} / \mathrm{ml}$ \\
\hline Al.P. & $69 \mathrm{mU} / \mathrm{ml}$ \\
\hline BUN & $13 \mathrm{mg} / \mathrm{dl}$ \\
\hline BSR & $135 \mathrm{~mm} / \mathrm{hr}$ \\
\hline Chest X-Ray & n.p. \\
\hline Bone X-Ray & n.p. \\
\hline
\end{tabular}

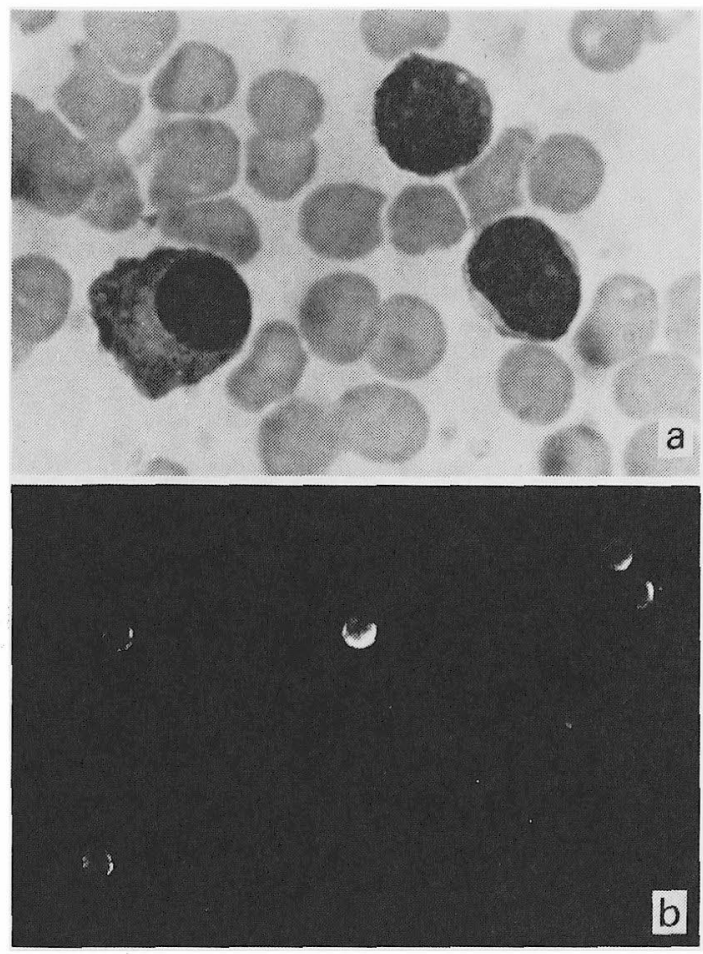

図 1。骨髄，塗抹標本 (Wright-Giemsa染色) (a). 招 よび末梢リンパ球の蛍光染色(b).

a：骨骾にはリンパ球, 形質細胞様リンパ球, 形質細 胞など多彩な形態を示す腫湟性B細胞が認められる. b： 末梢リンバ球のFITC標識抗IgA抗体による営光 染色では，大部分がSm IgA陽性細胞である.

入院時検查成績(表 1 , 四 $1 \mathrm{a}$ )：末梢血では， 軽度の負血と大多数がリンパ系細胞よりなる白血 球増加を想めた。このリンパ系細胞の大半は形態 学的に成熟にみえる小リンパ球であつたが，少数 (約10\%)は胞体がやや広く，形質細胞との移行を 示す形質細胞様リンパ球であつた，骨髄でも同じ く, 有核細胞数は正常であるが，リンパ球 $(45 \%)$, 形質細胞様リンパ球 (12\%)，形質細胞 (2.6\%) など多彩な形態を示すリンパ系細胞の著明な増生 が認められ，これらは形態学的類似性より同一ク ローン由来と推測されたが，これは後述の通り抗 idiotype抗体により確認した。血清総蛋白量は増 加しており，電気泳動像でfast $\gamma$ 域に明瞭なM成 分を認めた。これは免疫電気泳動法にて IgA $\varkappa$ 型 と判明した．免疫グロブリンではIgAの著増と 


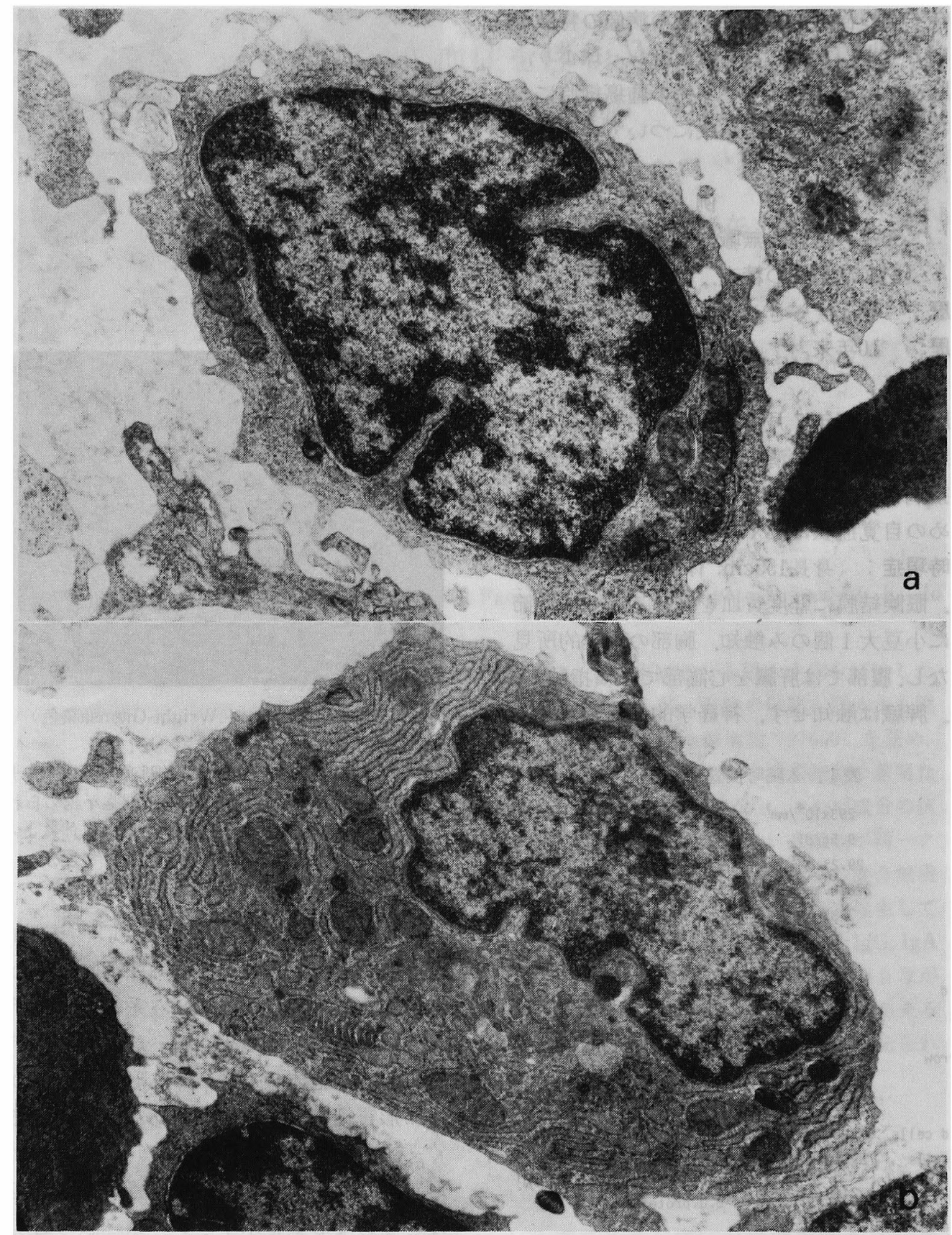

図 2 ，骨髄中腫瘍細胞の電顕像
$\mathrm{a}$ ：リンパ球 $(\times 7800)$
b： 形質細胞 $(\times 5800)$

IgG，IgMの中等度減少がみられた，尿中Bence Jones蛋白は陰性. 肝抢よび腎機能に異常なく, 全 身骨X線像にも骨髄腫にみられる骨融解像，病的
骨折，骨粗鬆症などの異常を認めなかつた。 末梢リンパ球の表面markerの検索（表 1，図1 b)： 細胞膜 $(\mathrm{Sm}) \operatorname{IgA}$ は大多数に陽性でしかも 


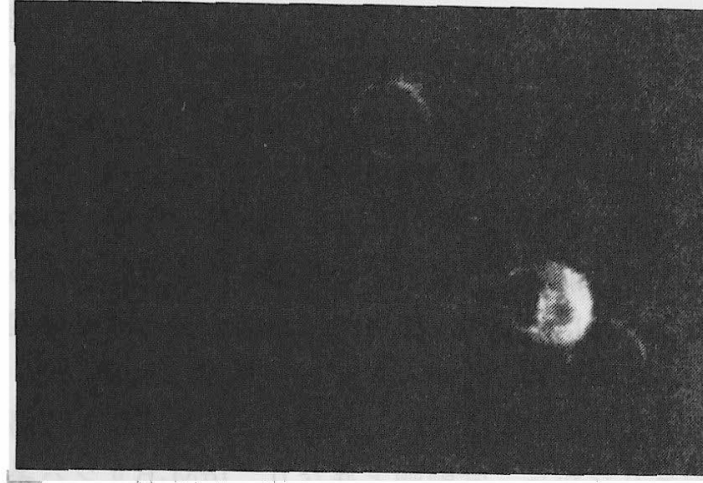

図 3 . 抗idiotype抗体を用いた賞光染色. 骨䯑道中のリン パ球から形質細胞にいたる各段階のBリンパ系細胞は 抗idiotype抗体により蛍光染色された。

$\boldsymbol{\varkappa}$ 型であり，末梢血中に増生する腫瘍細胞は B リ ンパ球系で単クローン性のものと考克られた。さ らにその多くは，Fcyレセプター拉よびIa like antigenが陽性であつた。一方，E口ゼット形成細 胞は $9 \%$ と减少していた。

腫瘍細胞の電顕像（図 $2 \mathrm{a}, \mathrm{b}$ ）：一骨髄穿刺によ り採取した腫瘍細胞の電顕的観察を行なつた。光 顕レベルで確認されたと同様に，腫瘍細胞は多形 性を示した，本例の腫瘍細胞は核の弯入が共通し てみられ，リンパ球段階のものでは核周のへテロ クロマチンは明瞭であつたが核小体は明瞭でなか つた. 粗面小胞体(rER), Golgi野の発達は不良で, ミトコンドリアは必ずしも多くはなかった。また 多くの場合, 細胞質全体の電子密度は高くなかつ た，形質細胞段階のものでは，核のへテロクロマ チンは乏しいが，核小体は汪とんど常に認められ た. Golgi野やrERの発達は良好で, rERは一部で は層状をなしているが，無構造物質をもつて霬状 に拡大したものもみられた。また細胞質の電子密 度はリンパ球段階のものに比して高かつた。

抗idiotype抗体による検討 (図 3)：本例の血 清中ょり $\operatorname{IgA} \boldsymbol{x}$ 型M成分を分離し，これを家鬼に 免疫して得られた抗血清の $y$ グロプリン分画を硫 安分画により分離した。これを 20 人の正常人血清 を結合せしめた BrCN, activated sepharose 4B columnk10回通した.このようにして得られた抗 血清は，抗原に用いたIgAのみと反応し，他のIgA
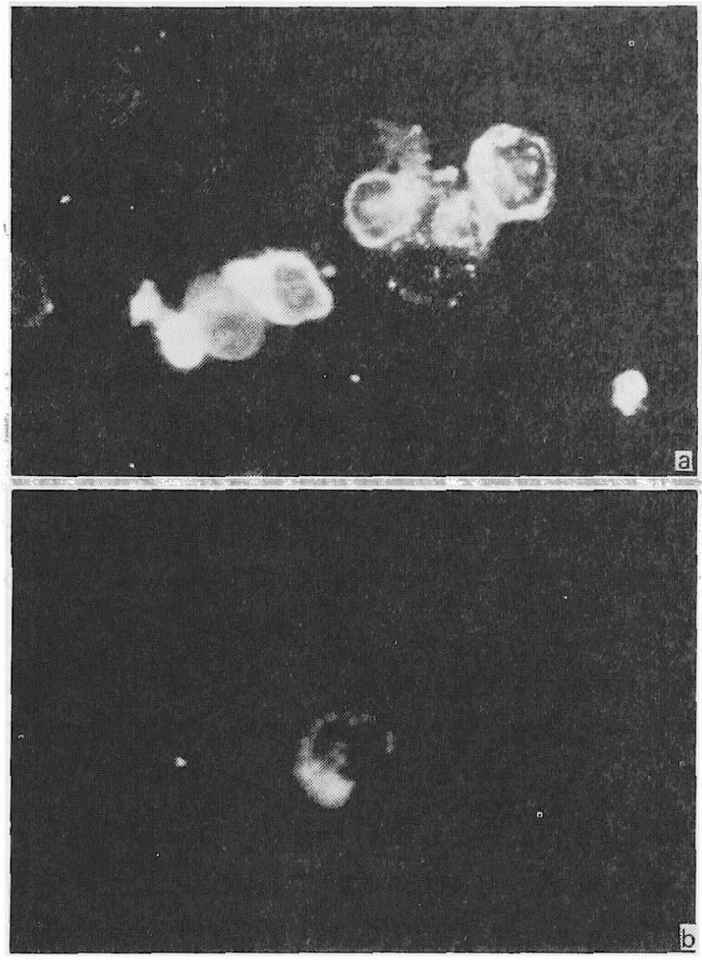

図 4.患者末梢リンパ球のin vitroにおけるIgA産生 能.

a：患者末梢リンパ球をPWM刺激下で正常人 T リンパ球と混合培湌すると, IgA産生形質細胞への分 化がみられた。

b：患者末梢リンパ球のみの培養では形質細胞は ほとんどみられなかつた。

型骨㵦腫蛋白 ( $\boldsymbol{\kappa}$ 型, $\lambda$ 型各 5 例) や正常人血清中 のIgAとは反応しないことを碓認した。この抗 idiotype抗体を用いて，末梢血リンパ系細胞の細 胞膜免疫グロブリン (Sm Ig)や骨髅リンパ系細胞 のcytoplasmic Igの蛍光染色を行なつた。その結 果, 形質細胞を含さ各種形態を示すリンパ系細胞 はすべて染色され，これらは形態から推測した通 り同一クローン由来のものであることが証明され た。

末梢血リンパ球のin vitroにおける分化：Fu らの方法 ${ }^{9}$ に準じ，患者末梢血リンパ球と正常人 T リンパ球をそれぞれ $1 \times 10^{6}$ 個に調整し，pokeweed mitogen (PWM) 刺激下に混合培養 (RPMI 1640）したところ，培養7日目にはcytoplasmic 
IgAが証明される形質細胞が出現し(図 $4 \mathrm{a}$ )，培着 上清にはIgAの分泌が証明された $(560 \mathrm{ng} / \mathrm{ml})$ 。し かしながら患者末梢血リンパ球のみの培養では形 質細胞は汪とんど出現せず（図 $4 \mathrm{~b}$ )，培羕上清に はわずかしかIgAの分泌が証明されなかつた（160 $\mathrm{ng} / \mathrm{ml}$ ).

\section{考 案}

近年リンパ球の発生，分化の詳細が明らかにな るにつれて，その分化，成熟の段階とリンバ系腫 演化の発生段階との関係が注目され，とくにBり ンパ系腫瘍では両者の相互関係がかなり明確にな つてきた ${ }^{10) 11}$. このため従来の形態学のみに頼つ ていたために生じたリンパ系腫瘍における混乱 も, 現在では次第に解決され, 臨床家にとつても リンパ系腫县に対しての対応が容易になつてきて いる、一方ここでとりあげる本例のよらな症例は， 実験動物から主として得られたリンパ球の発生, 分化の所見が，人間に括いても多くの面で適応可 能であることを示唆するとともに，基礎免度学を 臨床医学へ応用することの重要性を証明している とい克ら。

骨䯣リンパ球幹細胞は, Ia like antigenの発現 と細胞質内IgM合成開始により，Bリンパ球前駆 細胞（pre B細胞）に分化する．次に細胞質IgMを 失ない，代つて細胞膜上に $\operatorname{IgM}( \pm \operatorname{IgD})$ を持つ未 熟Bリンパ球 (early B細胞)となる。攵の後, early B細胞のSm IgがIgM $\rightarrow \operatorname{IgG} \rightarrow \operatorname{IgA}$ の順に発現する とともに，FCレセプター，C3レセプターを獲得

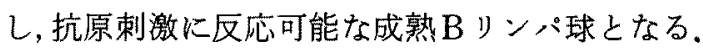
これは抗原刺激をらけると， Tリンパ球の影響の もとに細胞質内にIgを持つ形質細胞様リンパ球, さらには形質細胞へ分化する ${ }^{22}$. Bリンパ系腫煌 は，このようなBリンパ球から形質細胞にいたる 分化過程の一定の段階で腫瘍化をきたしたるのと 考兄られ，pre B細胞 (ALLの一部), early B細 胞 (B-CLL, non Hodgkin lymphomaの一部), IgG，IgA座生形質細胞（骨髄腫などの一様な (monomorphic) 増殖状態が知られている。一方, $\gamma$-heavy chain diseaseとならんで原発性マクロ グロブリン血症では増殖細胞が多形性（pleomor.
phic）であることが特徴である.CLLの腫痬細胞 は大半はSm IgMやSm IgG陽性リンパ球である が，原発性マクログロプリン血症のそれは，Sm IgM陽性リンパ球からIgM分泌形質細胞にいたる 各段階のBリンパ球が出現している(1011113144).この ことは, 前者では腫瘍化後腫瘍細胞の分化がみら れないのに対して，後者では腫瘍化後も腫瘍細胞 のある程度の分化がみられると考えられる ${ }^{1013)}$.

ところで近年, IgGやIgA-B リンバ系細胞の腫瘍 でありながら，骨髄腫と異なり，IgM-Bリンパ系 細胞の腫瘍である原発性マクログロブリン血症に みられる多型性のある細胞増殖を認める症例が， 希ながら報告されるよらになつだー8)，本例はま れにそのよらな例であり，とくに本例のごとく IgA型の場合は，現在までに本例を含めてわずか に 7 例報告されているにすぎない(1) 315)6/8).

本例にみられた形態学上多様性のある睡瘍細胞 は，血清中のIgA型M成分を家鬼に免疫して作製 した抗idiotype抗体による検討より，末梢血，骨䯣 のいずれの場合も同一クローン由来のものである ことが明らかになつた。したがつてこれらの細胞 が，血清中の $\operatorname{IgA} \varkappa$ 型M成分を産生する細胞群と 考学てよい。このよらな血清中のM成分と末梢り ンパ球のSm Igのidiotypeが同一であることは, 原

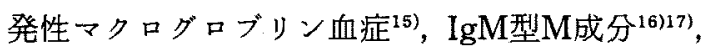

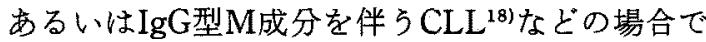
も明らかにされている。また血清中にはIgG型M 成分のみを認め, cytoplasmic IgはIgG $x$ 型あるい はIgA $\varkappa$ 型を持つ二つのpopulationを有するCLL に和いて，IgG $\varkappa$ 型とIgA $\varkappa$ 型のidiotypeが同一で あることを証明した報告すある ${ }^{19}$ ，さらに本例末 梢血リンパ球と正常人 Tリンパ球をPWM刺激下 で混合培養すると，リンパ球から形質細胞への分 化がみられたことからも，多彩な形態を示すリン ハ系細胞の同一クローン由来が明らかである. Fu らは, IgM型M成分を伴つたCLLのリンパ球につ いて同様の成績を報告している19).なお，このよう なin vitroでのリンパ球の分化は，Sm Igに対する 抗idiotype抗体により阻止されることも示されて いる20). 
表 2，原発性マクログロブリン血症の病像を呈するIgA monoclonal gammopathyの 報告例

\begin{tabular}{|c|c|c|c|c|c|c|c|}
\hline & $\begin{array}{l}\text { Hijmans } \\
(1975)\end{array}$ & $\begin{array}{l}\text { Manconi } \\
(1975)\end{array}$ & \multicolumn{2}{|c|}{$\begin{array}{l}\text { Trusz } \\
(1977)\end{array}$} & \multirow{2}{*}{$\begin{array}{l}\begin{array}{l}\text { Child } \\
(1977)\end{array} \\
40\end{array}$} & \multirow{2}{*}{$\frac{\begin{array}{l}\text { Levine } \\
(7980)\end{array}}{78}$} & \multirow{2}{*}{$\frac{\begin{array}{l}\text { Present case } \\
(1981)\end{array}}{57}$} \\
\hline Age & 73 & 64 & 58 & 80 & & & \\
\hline Sex & M & $F$ & $F$ & $F$ & $\mathrm{~F}$ & $M$ & M \\
\hline Hepatomegaly & - & - & ++ & - & + & - & + \\
\hline Splenomegaly & - & + & ++ & ++ & + & + & - \\
\hline Lymphnode en largement & - & - & - & - & 7 & - & - \\
\hline Bone lesion & - & - & - & - & - & - & - \\
\hline \multicolumn{8}{|l|}{ Peripheral biood } \\
\hline Hemoglobin $(g / d l)$ & 7.0 & 8.0 & 9.0 & 7.0 & 7.3 & 11.7 & 9.5 \\
\hline WBC & norma 1 & 15000 & 5400 & 1400 & 5900 & $\cdots$ & 27600 \\
\hline $\begin{array}{l}\text { Lymphoid cells (\%) } \\
\text { Bone marrow }\end{array}$ & -- & 96 & 32 & 41 & 59 & $680 / \mathrm{m}^{3}$ & 90 \\
\hline Lymphoid cells (*) & increased & 80 & 88 & 76 & 28 & $\cdots$ & $57.0-86.5$ \\
\hline Plasma cells $(\%)$ & $<3$ & 6 & 6 & 23 & 12 & $\cdots$ & $2.6-1.0$ \\
\hline \multirow[t]{2}{*}{ Monoclonal Ig } & $\operatorname{IgA}, \mathcal{K}$ & $\operatorname{Ig} A, x$ & $\operatorname{IgA}$ & $\operatorname{Ig} A$ & $\operatorname{Ig} A, \lambda$ & $\lg A, \mathcal{K}$ & $\operatorname{Ig} A, K$ \\
\hline & $3400 \%$ & $5.6 \mathrm{~g} / \mathrm{dl}$ & $5.3 g / d l$ & $3.8 \mathrm{~g} / \mathrm{dl}$ & $4.5 \mathrm{~g} / \mathrm{dl}$ & $2.8 \mathrm{~g} / \mathrm{d} 1$ & $4.2 g / d 1$ \\
\hline
\end{tabular}

最後に，原発性マクログロブリン血症に相当す るIgA型のそれの病像（これを一応Waldenström 型単クローン性IgA血症と称した)について, 本例 を含めた既報告例をまとめた（表 2)。その共通し てみられる特徵としては，IgA型骨隨腫の場合と 同程度の大量のIgA型M成分がみられる, 腫瘍細 胞の骨髄への漫潤を認めながら，骨破壊像はみら れないなどである。また現在までの報告例では， 原発性マクログロブリン血症の場合と異なり，末 梢リンパ節腫大を呈する例は知られていない。

\section{結語}

原発性マクロダロブリン血症に類似する病像を 呈しながら，M成分がIgA型である症例を報告し た、かかる症例は極めて希で，本例を含めてわず かに 7 例の報告しかみられないが，B細胞腫瘍の 中で特異な位置を占めるすのと考えられる。なお， 抗idiotype抗体を用いて本例の多彩な形態を示す リンパ系細胞が，同一クローン由来のものである ことを証明した。

謝辞 末梢リンパ球の表面markerの検索をしていたたい た京都大学内科第一講座 北邼吉先生に深謝します。

\section{文献}

1) Manconi PE, et al: "D-lymphoproliferative disorder" with $\operatorname{IgA} \kappa \mathrm{M}$ component in serum. New Engl J Med 293: 1102, 1975.

2) Hijimans $W$ : Waldenström's disease with an
IgA paraprotein. Report of a case. Acta Med Scand 198: 519, 1975.

3) Child JA, et al: Pleomorphic B cell neoplasm with monoclonal IgA secretion. A case report. Cancer $40: 2948,1977$.

4) Resegotti L, et al: Waldenström-like immunocytic lymphoma with IgG serum M component. Acta Haematol $58: 38,1977$.

5) Tursz $T$, et al: Clinical and pathologic features of Waldenström's macroglobulinemia in seven patients with serum monoclonal IgG or IgA. Amer J Med 63: 499, 1977.

6) Pangalis GA, et al: Malignant lymphoma, well differentiated lymphocytic. 1st relationship with chronic lymphocytic leukemia and macroglobulinemia of Waldenström. Cancer $39: 999,1977$.

7）赤坂清司, 他：原発性マクログロブリン血症の像 を呈する単クローン性IgG血症一新疾患单位の提 唱一(抄). 日血会誌 $41: 366,1978$.

8) Levine AM, et al: Clinical and immunologic spectrum of plasmacytoid lymphocytic lymphoma without serum monoclonal IgM. Brit J Haemat $46: 225,1980$.

9) Fu SM, et al: Induction of in vitro differentiation and immunoglobulin synthesis of human leukemic B lymphocytes. J Exp Med 148: 1570, 1978.

10) Salmon SE and Seligmann M : B-cell neoplasia in man. Lancet $11:$ 1230, 1974.

11) Lukes RJ, et al: A morphologic and immuno- 
logic surface marker study of 299 cases of nonHodgkin lymphomas and related leukemias. Amer J Pathol 90: 461, 1978.

12) Vitetta ES and Uhr JW: Immunoglobulinreceptors revisited. A model for the differentiation of bone marrow-derived lymphocytes is described. Science $189: 964,1975$.

13) Preud'homme JL and Seligmann M : Surface bound immunoglobulins as a cell marker in human lymphoproliferative diseases. Blood 40 : $777,1972$.

14) Siegal FP, et al: Surface markers in leukemias and lymphomas. Amer J Pathol $90: 451$, 1978.

15) Wernet $P$, et al: Idiotypic determinants of immunoglobulin $\mathrm{M}$ detected on the surface of human lymphocytes by cytotoxicity assays. J Exp Med 136: 650, 1972.

16) Fu SM, et al: Idiotypic specificity of surface immunoglobulin and the maturation of leuke- mic bone-marrow-derived lymphocytes. Proc Nat Acad Sci 71: 4487, 1974.

17) Hurley JN, et al: Lymphoblastoid cell lines from patients with chronic lymphocytic leukemia : Identification of tumor origin by idiotypic analysis. Proc Natl Acad Sci 75 : 5706, 1978.

18) Schroer KR, et al: Idiotypic uniformity of cell surface immunoglobulin in chronic lymphocytic leukemia. J Exp Med 140: 1416, 1974.

19) Rudders RA and Ross R: Partial characterization of the shift from IgG to IgA synthesis in the clonal differentiation of human leukemic bone marrow-derived lymphocytes. J Exp Med $142: 549,1975$.

20) Bona CA and Fauci AS: In vitro idiotypic suppression of chronic lymphocytic leukemia lymphocytes secreting monoclonal immunoglobulin $\mathrm{M}$ anti-sheep erythrocyte antibody. J Clin Invest $65: 761,1980$. 